\title{
Antagonism and Democratic Citizenship (Schmitt, Mouffe, Derrida)
}

\section{Matthias Fritsch}

\section{Concordia University, Montréal}

(preprint, postrefereeing version of article that originally appeared in Research in Phenomenology 38 (2008) 174-197; original article available at http://brill.publisher.ingentaconnect.com/content/brill/rip/2008/00000038/00000002/art00003; DOI: $10.1163 / 156916408 X 286950)$

\begin{abstract}
:
In the context of the recent proliferation of nationalisms and enemy figures, this paper agrees with the desirability of retaining some of the explanatory and motivational potential of an agonistic account of politics, but gives reasons not to accept too much of Carl Schmitt's account of citizenship. Th e claim as to the necessarily antagonistic exclusion of concrete others can be supported neither on its own terms nor on Derridian grounds, as Chantal Mouffe, in particular, attempts to do. I then indicate that différance may nonetheless account for strong (but not necessary) tendencies toward exclusion as well as for the intrinsic contradictions of liberal universalism.
\end{abstract}

Keywords: Mouffe, Laclau, Derrida, antagonism, citizenship, Schmitt

In political theory, both European and Anglo-American, citizenship theory has recently become a trend. There appear to be several reasons for this, both theoretical and empirical. First, the debate between liberals and communitarians having reached a stalemate, an obvious move beyond it was to focus on issues that combine individual rights, or private citizenship, with group membership, or public citizenship. Likewise, the reconsideration of the historical and systematic relationship between liberal rights and collective self-determination, in part prompted by the move toward a less aggregative, more deliberative understanding of democracy, led to renewed interest in democratic virtues beyond the concern for merely institutional justice: civic virtues such as the willingness to participate in debate, to openly tolerate difference, to promote the public good even at one's own expense, one's sense of inclusion in group identity, and so on. ${ }^{1}$ 
These theoretical shifts then require that political theory not only project the basic normative framework for just institutions, but concern itself with sources of motivation other than self interest, that is, beyond what enforceable law can do, as well as with the construction of political identities in a moral and political psychology.

These shift in the theoretical terrain respond, however, also to recent political events, both domestic and global. Voter apathy and civic privatism appear coupled with powerful new nationalisms in the context of the fear of globalization and increasingly multicultural memberships. After 1989 and the breakdown of the bipolar world order, the global public also witnesses the proliferation of new enemy figures despite the now hegemonic language of democracy and universal human rights. Against this background, citizenship theory would be charged not only with the theoretical-psychological task of accounting for civic virtues, but also with the diagnostic one of explaining the emergence of 'archaic' motivations directed at often inauthentic and unhelpful enemies.

The resurgence of interest in the work of Carl Schmitt may be explained by his apparent ability not only to articulate a lingering discontent with the triumph of liberalism after 1989, but the explanatory framework he offers to account for the veritable explosion of new enemies at the end of and after the Cold War as well as a theory of group identity and associated modes of civicpolitical motivation. However, this very framework, promising as it sounds, contains central theses that many, especially on the left, find unpalatable, and not only because of Schmitt's well known anti-Semitism and collaboration with the Nazis: the thesis of war as not only the ultimate in politics, but as grounding it, thus rendering the 'existential', 'concrete' enemy ineradicable; the thesis of the indivisible sovereign above the law, perhaps tainted by nostalgia for the Westphalian nation-state system; the all-too-clear division between 'the political' and the moral, economic, 
and private spheres, thus disallowing the crisscrossing of the various spheres of social and political life. For Schmitt, the political citizen needs an enemy who is neither her economic competitor nor one with whom she disagrees morally or in conversation, and thus seems rather remote from the moral and dialogic being with understandable economic concerns that most of us take ourselves to be:

The enemy is not merely any competitor or just any partner in a conflict in general. He is also not the private adversary whom one hates. An enemy exists only when, at least potentially, one fighting collectivity of people confronts a similar collectivity... The political is the most intense and extreme antagonism, and every concrete antagonism becomes that much more political the closer it approaches the most extreme point, that of the friend-enemy grouping (CP $28 \mathrm{f}$.).

It appears hard to deny that many are in fact united and motivated by the fear of an enemy, and that the public denial of public enemies, for instance by the supposition of an allinclusive consensus around human rights, allows their moralistic degradation into an evil one can only eradicate, not politically confront. Some theorists of citizenship then feel the desirability of retaining the explanatory account, and perhaps some of the political psychology, without having to subscribe to the unstomachable theses. Much of the recent interest in Schmitt's work is devoted to this task; Chantal Mouffe's work, in part in collaboration with Ernesto Laclau, might be exemplary in this regard. She argues that the two desiderata can be retained in a new account of political citizenship while transforming and mitigating antagonism into the less physical, less mortal agonism. Although the us/them distinction is politically uncircumventable for creating motivated unity, and thus politics at all, Schmitt never understood the 'democratic revolution' as bringing with it not only the legal framework of citizen rights, but also the possibility of viewing the 'them' as merely an adversary rather than an enemy whom 'we' confront, in the extreme case, in a fatal encounter (DP 13). 
Thus, without accepting mortal combat as underlying all of politics, we can still argue that Third Way liberalism, with its emphasis on consensus around human rights, neglects the inevitability of conflict and forecloses the option of identifying the true adversary, in terms of class, for example. It is thus that Blair, Clinton and Schröder, as well as, less convincingly perhaps, Rawls and Habermas, have allowed right-wing populism to take over in Western 'democracies' by hegemonizing the political in relation to a false-moral or cultural—enemy. ${ }^{2}$ Domestically, this could be the alleged enemy of family values and religion; internationally, we would meet the terrorist. For if we do not channel the psychological energies of would-be citizens towards the adversary, agonism will degenerate into antagonism and a Schmittian enemy will have to be found (DP 5, 74). The enemy is in part created as one we cannot debate and disagree with politically by a moralistic discourse whose categories of good and evil do not permit the opponent to become an adversary who need not be eliminated, only fought: in this way, argues Mouffe, the hegemony of human rights discourse on the international scene not so much justifies, but contributes to its dark underside, for instance, international terrorism.

In this paper, I will agree with Mouffe on the desirability of retaining some of the explanatory and motivational potential of an agonistic account of politics, but I will seek to show that she still accepts too much of Schmitt's account of citizenship, in particular as concerns the necessity of excluding what for her remain concrete and identifiable others. ${ }^{3}$ One way of showing this is not only to examine the argument as to the conceptual necessity of exclusions on its own terms, but to confront with each other two of the legs on which her account stands, namely the work of Schmitt on the one hand and "poststructuralism and deconstruction" (DP 11), Derrida's work in particular, on the other. I will argue first that Derrida's quasi-transcendental 'infrastructures' ('différance', exemplarily) do not sufficiently support the thesis of inevitable 
exclusion of human others, as can be seen in particular by attending to Derrida's own reading of Schmitt. I will then proceed to indicate that différance may nonetheless account for exclusionary tendencies as well as for the intrinsic (conceptual and aporetic) contradictions in liberal universalism. The conclusion will show that Derrida can help us to negotiate this terrain regarding the nonnecessity but strong tendency toward exclusions from citizenship. In this way, we may hope to find a better way of preserving the explanatory power and motivational strengths of the agonistic model without the insistence on strife leading us to forget the political need for promises of nonviolence.

\section{II}

Mouffe's argument, which we could call an argument from the logic of determination, runs as follows. Liberal norms of equal respect for free persons require bounded communities for their effective exercise, institutionalization, and enforcement. Such institutionalized communities require, for their practical functioning, a sense of collective identity, which in turn can only be established by way of the exclusion of an 'other' in the face of which communal identity first wins cohesiveness. Hence, there can be no liberal democracy without an agonistic logic of oppositional strife, and without attempts to dominate (or 'hegemonize') the political sphere.

The crucial, but also controversial, step here is the second: the claim that the needed cohesiveness or identity can only be established by agonistic exclusions of concrete others that allow collective identity to form in the first place. By and large, it is not an empirical argument drawn from experience and historical examples, but a conceptual argument aiming to show the intrinsic unattainability of an all-inclusive and egalitarian liberalism for conceptual reasons. In 
both Hegemony and Socialist Strategy, co-authored with Ernesto Laclau, as well as texts singly authored, this conceptual claim is said to be supported by Derrida's notion of the generation of meaning in referential systems by way of 'différance'. For instance, in Hegemony - a book Derrida refers to in Specters of Marx ${ }^{4}$ - différance is enlisted in demonstrating the impossibility of fixing meaning once and for all (111 f.), an impossibility that must nonetheless be attempted by what Derrida called the "desire for the center in the constitution of structure." "Antagonism' is then presented as the inevitable result of attempting to attain closure or frictionless 'objectivity' (122 ff.); given the necessary but impossible attempt to close the political, its unity will always be usurped by only a particular element of it, which in turn must meet with antagonistic opposition by the inevitably excluded. ${ }^{6}$ In what follows, I will single out the version of this thesis as presented in Mouffe's recent work, for this work presents the thesis in its, for a theory of citizenship and motivation, perhaps most useful but also strongest form by drawing on the work of Carl Schmitt to conceptualize the space of the political as antagonistic. Despite the centrality of Schmitt and his work's deconstructive reading in Politics of Friendship, the reference to Derrida remains central to Mouffe; The Democratic Paradox in particular refers to différance by way of "the constitutive outside" said to ground the thesis of antagonistic exclusion (DP $12 \mathrm{f}$.).

Before we assess this argument, we should briefly consider the early Derrida's arguments on which both Laclau and Mouffe draw. What does 'différance' mean so that it could lead one to the idea of necessary exclusions, and, in a second step, to viewing political relations as necessarily antagonistic? As is well-known, 'différance' combines the sense of differentiation with that of deferral. As in Saussure, elements in a system of referral require the distinguishing reference to another element to establish their (minimal) identity, that is, their capacity to 'refer', signify, and hence to transport meaning. First of all, then, différance names the empty gap, the 
differential relation, between elements without which they cannot function. Secondly, however, the deferral aspect of différance also signals that the differentiation process never comes to a close, but is begun anew with each new instance of an element's use or occurrence. If the set of elements were in principle finite, as in Saussure's theory of la langue, the distinguishing relation would always pass through the same elements for all elements, thus providing them with a stability of meaning of which users of the structure of la langue can avail themselves in their parole, or actual speech.

If, however, one follows Derrida in denying the boundary between the structure and its use, between la langue and la parole, a necessary infinity of distinguishing references enters the system, which is now a quasi-system in the sense that its structurality consists in nothing other than its use or its event. Every use of an element must seek to return to its identity 'after' its necessary detour through all other signs, but this detour turns out to be infinite. An element must refer to the future of its identity, but this same future is simultaneously deferred to a 'to come' that never arrives as such. The future to come thus implies that identity is infinitely divided against itself, and hence, in open-ended and unforeseeable ways, infiltrated with the otherness needed to establish it. In other words, the distinguishing reference is both a condition of possibility of identity as well as, by way of the infinity of the reference, its condition of impossibility, if by identity we mean a final or simultaneous one. Identity is thus, as Derrida puts it in recent texts, aporetic.

It is, of course, tempting to transpose this aporetic logic to politics: not only does every element or mark need to constitute itself by the distinguishing reference to what it is not, but also the 'outside' must be excluded from the element's own "totalizing" attempt to return to itself. Since this attempt is always bound to fail precisely due to the otherness required, a certain 
violence in the constitution of identity is inevitable, a violence that one may argue results in antagonism between the included and the excluded. Thus, one may conclude, with Mouffe, that any political identity —of the individual citizen or the collective nation, of the proletariat or of women, etc. - can only be established by an antagonistic relation to an other who must be excluded from the identity. If this is so, the liberal-universalist project of considering all equally is necessarily bound to fail. As Mouffe puts it:

[C]oming to terms with the paradoxical nature of liberal democracy requires breaking with the rationalist dominant perspective and calls for a theoretical framework which acknowledges the impossibility of constituting a form of social objectivity which would not be grounded on an originary exclusion. This is why a continuous thread in my argumentation is to highlight the importance of a non-essentialist approach informed by post-structuralism and deconstruction for a proper understanding of democracy...In [Derrida's] case, it is the notion of the 'constitutive outside' which helps me emphasize the usefulness of a deconstructive approach in grasping the antagonism inherent in all objectivity and the centrality of the us/them distinction in the constitution of collective political identities (DP 12).

For Mouffe, then, the account of identity in view of différance helps us to grasp the inevitability of antagonism. To approach an understanding of why this move from différance to antagonism is too hasty, I will begin by raising three objections to the proposed combination of Derrida and Schmitt. It should be noted that these objections, while they certainly concern Schmitt's antagonistic logic, are to some extent recognized in Mouffe's text, if read generously, though at other times the text does not draw the right conclusion from this recognition. Hence, considering the implications of deconstruction for citizenship in view of Mouffe's extrapolation requires a rereading of Schmitt with différance in mind. It appears thus imprudent to neglect Derrida's own reading of Schmitt in Politics of Friendship, for it is on this basis that we can proceed to clarify the differences between Mouffe and Derrida, differences that will be guided by the idea of casting the 'constitutive outside' not in terms of the adversary but différance. 
My first point then is that the relation between identity and its other is not exclusionary of a clearly demarcated 'outside', as for Derrida identity is not so much marked by excluding defined others, but by the infinite porosity of a supposed inside and outside, and hence its constant re-negotiation (1). My second and third points here show that even if such exclusion was inescapable on Derridean grounds, this exclusion neither necessarily excludes concrete human others (2) nor is it necessarily antagonistic (3). All of the three points, which I will present a bit schematically here, are confirmed by Derrida's own treatment of Carl Schmitt, on whom Mouffe in particular draws in order to establish the thesis of inescapable antagonism. ${ }^{8}$

(1) Let's begin with the first counter-argument. Although Mouffe does not refer to any specific text in which the notion of the 'constitutive outside' is discussed, we may assume that she takes it to originate in the context of the early Derrida's discussion of Saussure's relation to writing in Of Grammatology, especially the two sections that treat the relation between the inside and outside (OG 33-65). Derrida's overall strategy, as we saw, is to move away from Saussure's attempt to close the referential system of la langue by distinguishing it from la parole, that is, actual instantiations of speech. If this distinction is not simply assumed, the structural closure cannot establish itself: in each speech act, the differentiation process Saussure reserved for $l a$ langue is begun anew. In order for Saussure to establish secure boundaries around la langue and the scientific discourse that treats it (OG 33), it was necessary to exclude 'writing' from it as a mere, even perverse, figuration of the inner workings of the linguistic system. It is this writing, of course, which Derrida generalizes as an archē-writing (OG 55) that, as another name for différance, is prior to the differentiation between speech and writing in the ordinary sense. Hence, the deconstructive reading of Saussure traces the many ways in which Saussure both excludes phonetic writing, the "sign of a sign", from la langue, for it is merely a secondary derivation from 
speech (OG 35), and is forced to reintroduce it as, in fact, best expressing the essence of language as the differential relations between signs, so that every sign is a sign of a sign (OG 42, 66, 68). Hence, Derrida can conclude:

The outside bears with the inside a relationship that is, as usual, anything but simple exteriority. The meaning of the outside was always present within the inside, imprisoned outside the outside, and vice versa (OG 35). [...] The system of writing in general is not exterior to the system of language in general, unless it is granted that the division between exterior and interior passes through the interior of the interior or the exterior of the exterior, to the point where the immanence of language is essentially exposed to the intervention of forces that are apparently alien to this system (OG 43).

Hence the need to think an originary writing that, by being prior to the division between la langue and la parole, between speech and secondary writing, makes both possible in such a way that no clear division between them, and that means between the structure and its opening, between the outside and inside, can be thought. It is in order to capture this condition of possibility that Derrida approaches the language of the 'constitutive outside':

It is because archē-writing, movement of différance, irreducible archē-synthesis, opening in one and the same possibility, temporalization as well as relationship with the other and language, cannot, as the condition of all linguistic systems, form a part of the linguistic system itself and be situated as an object in its field. (Which does not mean it has a real field elsewhere, another assignable site.) (OG 60)

The constitutive outside, then, is différance. As the merely empty spacing between elements or mark, the blank space between graphemes, it is not itself a mark and thus outside the system, but at the same time, it is inseparably inside, for as a mere empty gap, it cannot be detached from the elements it nonetheless co-constitutes. Every relation, even a differential one by way of nothing but an empty spacing, is inseparable from its relata. Hence, différance is outside but not elsewhere. This is why the title to the section in which Derrida discusses the 'constitutive outside' is "The Outside [is] the Inside" (OG 44), with the copula crossed out. 
It is thus mistaken to refer the constitutive outside to a Schmittian logic of antagonism, as the latter presupposes that the self is established in conflictual relation to a concrete human threat. Neither the conflict (see point 3) nor the concreteness of the outside (point 2) follow from différance. But our first point concerns the self: if there never is a clear dividing line between identity and its allegedly excluded other, identity must rather be understood as the perpetual attempt to cast to the outside that which, however, is always needed on the inside. The attempt thus necessarily fails. As Derrida put it much later in Archive Fever, where identity is called the One:

As soon as there is the One, there is murder, wounding, traumatism. L'Un se garde de l'autre. The One guards against/keeps some of the other. It protects itself from the other, but, in the movement of this jealous violence, it comprises in itself, thus guarding it, the self-otherness or self-difference (the difference from within oneself) which makes it One. The "One, differing, deferring from itself". The One as the Other."

Thus, if the One is never finally established, neither is the other; deferral affects both. In the context of his discussion of Carl Schmitt, as we will see, Derrida makes this point by arguing that the external enemy claimed, in Schmitt's early work, to be needed for the establishment of political identity, turns out to be superseded by the domestic enemy in later work, in such a way that 'external' and 'domestic' are themselves constantly at issue. In his prison writings, as Derrida is keen to unearth, Schmitt then even concedes that the enemy is the brother, or, still closer to home, to the home of friendship, the self itself (PF 149, 162ff., 216).

(2) This failed arrival at an outside other and at a reassuring dividing line between inside and outside already indicates the second point, to wit, the counterargument that the excluded other never settles into a concrete, identifiable other. Mouffe conflates the Derridian point about the constitutive role of otherness for any identity with the claim that what must be excluded are human others. For her, not only is the relation to otherness necessarily antagonistic, but 
"antagonism...is inherent in human relations" (DP 101) so that the antagonistic relation necessarily holds, as in Schmitt, between identifiable human groups Mouffe calls 'us' and 'them'. In Schmitt, of course, this restricting of the other in terms of human beings follows from the Hobbesian premise that human life can be threatened with murder only by fellow creatures, and that any political theory that does not begin with the assumption that man is evil cannot be genuine (CP 61). Mouffe thus inadvertently combines the "nonessentialist approach informed by post-structuralism and deconstruction" (DP 12) with what Schmitt himself calls a "political anthropology" (CP 60).

Mouffe's claim here-that differential relations lead to the necessary exclusion of concrete human others - may thus be rebutted by saying, as Arash Abizadeh argued in relation to both Mouffe and Schmitt, ${ }^{10}$ that the 'other' needed for 'identity' does not necessarily coincide with concrete human others; what needs to be attempted to be excluded may be an imaginary value, a phantasm, or the gods, animals, and so forth. For instance, the collective identity of the notion of humanity that underwrites both Kantian ethics and discourses of universal rights may be established by differentiating humans (no doubt problematically) both from gods and from animals. $^{11}$ In Politics of Friendship, Derrida confirms this point by attacking Schmitt's assumption that the sovereign is sure of who the enemy is: the absence of a clear dividing line between friend and enemy rather implies uncertainty, the possibility of error, and even confusion between 'us' and 'them' (PF 69, 106, 127). At the same time, Derrida diagnoses an "obsessive” attempt on the part of Schmitt to concretize the other and to thus fix politics in a presentist ontology (PF 138, 116f.), precisely at the point when, some time in the twentieth century, it became more and more obvious that the old system of sovereign nation-states and their borders had come under various sorts of pressure (PF 246 f.). The real enemy of Schmitt's reactive 
'obsession', then, might not only be liberal humanism and telecommunications not easily confined to a territory, but those who resist identification as friend or enemy, the "natural existence of groups of individuals who just happen to live together". ${ }^{12}$

(3) The third point here claims that, even if exclusions were inevitable as well as taking identifiable individuals or groups as their object, the relation to the excluded need not be antagonistic. There is no différance-based reason as to why the other needed for (always incomplete) self-identification has to be an enemy, not even one, as Mouffe would say against Schmitt, whom one does not seek to destroy, but only to oppose as an "adversary" rather than an "enemy" (or a "friendly enemy"; DP 13). For instance, a friend-friend relation beyond Schmitt's “oppositional or "polemological' logic" (PF 246), beyond "ontological adversity" (PF 249), may be quite sufficient to establish identity, without this, of course, implying the possibility of a nonviolent polity. Despite her allegedly deconstructive conclusion as to the inevitability of antagonism, Mouffe recognizes at one point that apart from conceptual reasons, empirical factors have to come into play for the emergence of antagonistic relations: "If collective identities can only be established on the mode of an us/them, it is clear that, under certain conditions, they can always be transformed into antagonistic relations" (DP 13). A bit later, she describes these conditions as "the power relations which structure contemporary post-industrial society" including the "wealth and power of the new class of managers [of the capitalist system]" (DP 15). As we will see after considering Derrida's reading of Schmitt in greater detail, it is indeed worthwhile to consider the reasons that transform a différantial relation into an antagonistic one, but not without insisting that such a transformation is not a conceptual necessity, and hence is to be rethought from the viewpoint of différance as an archē-friendship (PF 24) prior to the difference between enmity and friendship (PF 249). 
I would now like to coalesce these three arguments-(1) the indescernibility or convertibility of friend and enemy, (2) their lack of concrete identity and full presence, and (3) the possibility, but not necessity, of antagonistic relations-by paying closer attention to Derrida's overall case against Schmitt in Politics of Friendship. We can distil the argument by focusing on the ambiguous nature of the sovereign subject deciding on its enemy. It is this matter with which Derrida in fact begins his lengthy discussion of Schmitt, a discussion characterized throughout by the "aporia of decision" that makes every decision the decision "of the absolute other in me, the other as the absolute that decides on me in me" (PF 69).

As is well known, Schmitt thinks the political from the viewpoint of sovereignty as well as enmity: sovereign is he who decides on the state of exception, and in this exception a decision is made on the friend and the enemy. This decision is viewed, as we saw, as the foundational institution of the political as opposed to the moral, religious, economic, or private. Hence, there can be no politics of an all-inclusive humanity; the liberal discourse of human rights hides its own exclusiveness by casting the enemy it still needs into subhuman categories. What we have here in Schmitt is the well rehearsed problem of the 'co-originality' of friend and enemy, of citizen and other: the identificatory decision on the enemy both presupposes as existing and first of all creates the self. While this problem of co-originality is well known in the secondary literature, it is rarely addressed as ineluctably aporetic, as Derrida does not only with regard to Schmitt, but also in his analysis of Jefferson's Declaration of Independence, a declarative act that likewise presupposed the free United States it first of all inaugurated. ${ }^{13}$ The sovereign thus 
emerges out of an anachrony, a disjointure in time that alone can explain, or rather perform and enact, its generation, an emergence in dehiscence dividing the decision-making subject against itself in presupposing an otherness it needs but cannot master. This well known problem thus already shows an anterior otherness installed in the very heart of the citizen-collective, or its sovereign representative, and it also already indicates the precedence of an otherness that the self cannot ever quite rid itself of by casting it to its outside, try as it must.

We can also look at this otherness - différance, what else but everything?-from its other side, by viewing it as embodied, in a forever incomplete and impure incorporation, in the enemy the self thus needs. For on the one hand, it would seem that to be the sovereign decision-maker as which Schmitt understands it, the self must freely decide on its enemy so as to engender him independently of real, existential, and exterior others. If the sovereign were determined from the outside in its decision, it could hardly be said to be the sovereign and autonomous self as which Schmitt understands it, for its decision would be made for it by the other. However, if the sovereign decides freely, the enemy qua the self's own creation would be immanent to the self and not outside, friendly to it insofar as it allows the self to emerge, and not hostile. This is of course why Derrida says that a decision proceeding from the sovereign identity of a subject "never decides anything", for one would already know in advance what the subject will decide, thus confusing decision with a program or a machine (PF 68). A sovereign thus disallows the decision on the enemy on which Schmitt nonetheless builds his case.

But — and this is the other hand - if the enemy is not created by the self as what it needs, but is in fact the very 'real' and 'existential' threat the political self must presuppose for its emergence, it seems we have no decision either. If the enemy exists prior to the self as exterior to it, no decision would be needed insofar as the precedence of the other as already concretely 
existing allows the self to emerge in passive exposure to a given other. There would be no need for the decision and the sovereign decision maker. Hence, the double identification of self and enemy requires first a living, sovereign decision maker, but second, its mortality, that is, a vulnerable self in advance exposed to the bellicose threat from the other, the other who thus constitutes the self as a unity gathered only by being threatened with extinction. Hence, self or other, sovereignty or vulnerability, life or death. This is how Derrida puts the "what comes first?" question:

The practical identification of self-and from one self to another-the practical identification of the other - and from other to other - seem to be [in Schmitt] sometimes conditions, sometimes consequences, of the identification of friend and enemy (PF 116).

If friend and enemy cannot thus pre-exist the encounter to which they owe themselves, we must think Schmitt's decision a little less decisionistically, that is, as co-generating self and other each time anew, but never ex nihilo. Rather, both emerge only in exposure to one another against the background of an inexhaustible history of prior identifications. The inexhaustibility of this past is indicated not only in the nonorigin of différance, but in the 'to come' that calls for always new decisions on friend and enemy. The nonhorizonal future is thus that which divides the sovereign against herself, installing the other as (neither concrete nor necessarily antagonistic) 'enemy'the one the self cannot admit into itself and yet has to beckon again and again-in its very home. So Derrida writes a little later, after Schmitt has been made to confess, in prison, to himself or his brother as his own enemy:

The enemy had indeed to be there already, so near. He had to be waiting, lurking close by, in the familiarity of my own family, in my own home...This enemy was a companion, a brother, he was like myself, the figure of my own projection, but an exemplarity more real and more resistant than my own shadow (PF 172).

If the self emerges only in différance, then, it must both presuppose itself and its other as already existing, and that means always phantasmatically presuppose and project them. Given the 
infinity, or what amounts to the same thing, the inexhaustive otherness of différance, we know in advance that the phantasm will remain ineradicable, and no concrete other can really, for instance in the finality of mortal combat, take the place of the Schmittian enemy. The war that Schmitt thus insistently calls for as the imminent actuality that alone gives the self by way of its enemy remains forever unreachable in its spectral suspension between actuality and possibility.

It is this aporia of the decision, then, that sketches the basic outlines of Schmitt's autodeconstruction: the ineluctable lack of knowledge and indeed constitutive undecidability as to who the enemy is (PF 69, 106); the becoming-internal of the enemy, from another sovereign state to the domestic enemy to the brother to, finally, the self as its own enemy (PF 162); the convertibility of friend and enemy (PF 32, 71, 88, 174); and Schmitt's slide from possibility to eventuality to the actuality of war and physical killing (PF 86), a slide also quite noticeable in Mouffe. ${ }^{14}$

Rather than pursue these elements of the deconstruction of the political further, it is time to return to Mouffe's appropriation of Schmitt to assess where Derrida and Mouffe differ. We are now in a better position to understand why we need not agree with the claim that political identity necessarily demands antagonistic exclusions of concrete, identifiable others. Derrida's own reading of Schmitt—which Mouffe, surprisingly, does not consider—shows that Mouffe draws on Schmitt at the risk of inheriting some of his views without attending to their autodeconstruction. As we have seen, while the 'outside' is constitutive of the self, it is never really 'outside', and the "originary exclusion" said to ground the political (DP 11) does not exclude a concrete and identifiable other. Rather, any collective identity must constantly but discontinuously invest itself in the always fragile and unstable distinction between self and other in a way that simultaneously internalizes the other. 
One may object here that Mouffe recognizes this in her own critique of Schmitt. For she too says Schmitt "retains a view of political and social identities as given" whereas his very antagonistic logic requires him to admit that "the existence of unity is itself a contingent fact which requires a political construction" (DP 54). To the extent that Mouffe recognizes this "contradiction" in Schmitt, she is right to seek the help of the "nonessentialist approach" of deconstruction to think the political articulation of identity and its other (DP $10 \mathrm{f}$.). She thus acknowledges what we called above thesis (2): the lack of concrete identity and full presence of friend and enemy.

However, she associates the deconstructive approach without further ado with the necessary exclusion of a concrete other, as if identity construction had built into it the telos of concrete exteriority, thus underestimating the significance of theses (1): the indescernibility or convertibility of friend and enemy, and (3): the mere possibility, but not necessity, of antagonistic relations. Let us then sharpen the analysis of this underestimation in the direction of five effects, all of which can be seen to follow from mistaking the constitutive outside for a human other rather than viewing it as différance.

\section{IV}

For what follows first of all from différance as the constitutive outside to which every self owes itself is only that identities have to negotiate their outside, to seek to cast to an imaginary outside that which is perceived as improper to their spheres of ownness. If the outside is not understood as a concrete and human other beyond the frontier of group identity, as Mouffe implies with the ubiquitous language of 'us' and 'them', but as différance, then there is in fact not 
only no good reason why the identity-conferring other must be a concrete 'them', but rather, we already know that the constitution of the 'them' as well as the of 'us' must always fail. ${ }^{15}$

Apart from this lack of a telos of concreteness, we can secondly note that this shift in understanding the 'outside' also implies that the true enemy/adversary, but also friend, of the political self is in fact différance. Thus, while the self needs to distinguish itself in its investments, in its attempt to return to itself with a profit, there is no a priori (though perhaps an a posteriori) necessity for the distinguishing references to relate to an agonistic or antagonistic other, a human other with whom the self is in conflict. There is of course, as we noted, such a reason in Schmitt, for whom the enemy must be able not only to cause the self to die, but to kill it. Once Mouffe abandons the notion of the mortal enemy and does not reintroduce, for example, a Hegelian logic of recognition restricted to oppositional human self-consciousnesses, the identity-conferring other may, however, be a mere symbol, a phantasmatic constructions, nonhuman beings, and so on.

Third, Mouffe, like Schmitt, appears to underestimate what we described as the familiarity or fraternity of the enemy, which again in the end is the différance that divides the self against itself. For Mouffe tends to follow Schmitt, in particular the early Schmitt and his nostalgia for the Westphalian world of sovereign nation states, in focusing on exclusions from 'the people':

As my discussion of Carl Schmitt's theses... makes clear, democratic logics always entail drawing a frontier between 'us' and 'them', those who belong to the 'demos' and those who are outside it. This is the condition for the very exercise of democratic rights (DP 4).

These exclusions said to be necessary for the effective exercise of rights seem to be external to the people of popular sovereignty, then, whereas we have seen that the self's obsessive convulsions and contortions are due to its ultimate impossibility of ridding itself of the 
demanding otherness within itself. More to Mouffe's point, it would seem that 'domestic' and always fragile, open-ended confrontations can do the job of motivation much better, in particular in directing political efforts of groups toward the 'true' adversary (e.g., the "managers of the capitalist system") as opposed to the one often generated by the moralistic right wing populism she see as exploiting the disastrous move to the consensual centre of Third Way liberalism.

Having already addressed the other as phantasm and demand, the fourth and fifth effects of misrecognizing différance as the ironically 'real' enemy concern them. The phantasm first. Derrida argues that since a self must seek to return from its investments to itself qua self, not qua other, and since différance turns every repetition into an alteration that makes this return impossible, the self has no other option but to deny the constitutive relation to the other as différance. For the latter cannot be acknowledged as such as it has no 'as such'; already giving it a name, moving the empty gap between marks into the position of one of the marks, is saying too much, or too little.

For what is also and at the same time at stake - and marked by this same word in différance-is différance as reference or referral [renvoi] to the other, that is, as the undeniable, and I underscore undeniable, experience of the alterity of the other, of heterogeneity, of the singular, the not-same, the different, the dissymmetric, the heteronomous. I underscore undeniable to suggest only deniable, the only protective recourse being that of a send-off [renvoi] through denial. ${ }^{16}$

With the inescapable denial of the heteronomous origin of the autonomous self, the self tends to, as a passage we looked at earlier had it, generate an enemy as "the figure of my own projection" which is nonetheless "more real and more resistant than my own shadow" (PF 172). While the self first of all phantasizes its coincidence with itself, denying the disjointure of time, it also leads it to displace the true adversary or friend toward another other, perhaps a projected enemy: as if the failure of the proletariat to constitute itself as Marx's nonspectral, world-historical agent and representative of universal humanity, for instance, was due to the class enemy, or, as in Stalin, to 
the ethnic enemy; as if the terrorist 'enemies' of the US people came from abroad, with a foreign religion, culture, and history, rather than being the suicidal executioners of its own "autoimmunity", and so on. ${ }^{17}$ The 'adversary' is thus never simply concrete, not only in the sense that 'he', 'she', or 'it' is, each time anew, in the process of reconstitution, but also in being spectralized, phantasized, or idealized. Here, Laclau, Mouffe, and Derrida concur in insisting on the importance of psychoanalysis for politics.

But this impossibility of recognizing différance as the 'true' enemy 'as such' also opens the range of its projection: from the mortal enemy whom 'we', the potential victims and upright citizens, have to attack pre-emptively (it matters little in the end whether 'he' had WMD or not), to the moralistically depoliticized enemy of the 'evil empire' or the 'axis of evil' or merely those who don't go to church on Sundays (and here Mouffe's recent analyses in On the Political are rather pertinent); but also from the other as oneself, as familiar brother or 'natural' friend (and the brother is, for Derrida, not only excluding the sister, but always a phantasmatic projection, as there is no 'natural' brotherhood; PF 92f.) to the other being even more symbolic and less real, which also means potentially less hostile, perhaps even being supernaturally idealized as a supreme being with whom the self finds itself in a love-hate relationship. ${ }^{18}$

Of course, Laclau and Mouffe would be right to claim, not a necessity but perhaps a strong tendency, for différance taking the shape of conflict, and not only the conflict it already signals as the dividedness between the self's phantasm of itself and its condition of possibility, but also and partly for that reason, the conflict with another phantasm, this time the phantasm of the other, even if these remain convertible and undecidable in the end. Hence, we might suggest that indeed, the counter-arguments should not blind us to the fact that empirically analyzable (and hence contingent) causes may transform the, from a conceptual standpoint, mere possibility of 
antagonism into a very strong tendency. In fact, as we have suggested, the tendency would be not just strong though still contingent, but proceed from the violence the self necessarily does to itself to become a One. For if the One must return to itself as itself but cannot do so, thus responding with a phantasm of self-coincidence, this phantasm must seek to expunge the other, even if this is done in naïveté, for instance, in the phantasm of the autonomous origin of autonomy. ${ }^{19}$ Indeed, quasi-transcendentally reinscribing the distinction between la langue and la parole, the structure and that which it structures, calls for a rethinking of the relation between conceptual necessity and empirical possibility so as to view contingency as necessity. ${ }^{20}$

Thus, just as conceptual arguments should not blind us to the actual empirical forces preventing the realization of the ideal of more universal solidarity across different groups, so conceptual counterarguments should not baulk at the strong tendencies toward exclusion generated by the juxtaposition of différance and certain empirical factors. While I cannot analyze and describe these empirical factors here (although such an analysis would bring, in very desirable ways, philosophy and the social sciences together), what I can do in the remainder of this paper is to suggest that deconstructive analysis also presents us with the 'tools', both quasitranscendental and normative, to negotiate this situation in which conceptual and empirical arguments intermingle in often impenetrable and unpredictable ways. Not only does deconstruction generally imply a call for a kind of vigilance and open mind about one's own assurances, for example, as to who the enemy and the friend are, and about whether a certain political phenomenon is based on human discursivity as such or on contingent conditions, but it also presents a model of political analysis that necessitates the promise of consensus that Mouffe and Laclau attack so relentlessly. 
Before we turn to this fifth effect, however, we should note that, while différance does not support necessary exclusions or even inevitable antagonism, it does hint at their likelihood under conditions of relatively scarce material resources being very unevenly distributed against a background of a 'phallocentric' history of inter-human domination and exclusion. The more past events and traditional symbolic structures have sedimented justifications for exclusions and oppressions as 'second nature', and the more individuals and groups battle for resources that a history of violence spreads unequally, the more such groups will display a tendency to (1) insist on the impermeability and depoliticization of supposedly 'natural' borders between inside and outside; (2) construe the inside and outside as affecting thus marked concrete human others; and (3) battle for and against - that is, around — such increasingly shifting borders, in particular, under modern conditions of an increasing functionalization and instrumentalization of action, coupled with an increasing de-traditionalization and its attendant loss of certainty. To counter these strong tendencies, however, it is neither necessary nor desirable to jettison the universal ideal of consensual citizen-solidarity; rather, the point is to recognize that a promise of consensus and nonviolence is as constitutive of the political as the impossibility of realizing it. Mouffe's opposition between rational consensus and antagonism, between Rawls and Habermas on one side and Schmitt and Mouffe on the other, would thus simply be too stark, too antagonistic to repoliticize democratic citizenship, and too limited in its range of foreseeable political motivation by excluding as naive, in what amounts to theoretical fiat, normative grounds for action.

For it is no accident that, in both the discussion of Schmitt and the debate with Laclau, as staged by Mouffe, Derrida insists on the way in which différance also implies an originary responsibility, an aimance or an archē-friendship, that must be understood as a promise of consensus and nonviolence. ${ }^{21}$ For in making possible, thus giving, the individual and collective 
self, différance, the 'true' adversary and friend, also obligates the self dissymmetrically and heteronomically. Since différance operates in language and by way of singular others from which it remains inseparable, such as our dead ancestors from whom we inherit language, it must also be thought as a gift or promise of language. And this promise, argues Derrida, is in part a promise of (albeit unattainable) consensus, thus putting him on this point in agreement with the transcendental pragmatics of Apel and Habermas, the consensus theorists Mouffe chastises for misrecognizing the political. Allow me to cite extensively from Derrida's oral response to Laclau's exploration of the value of deconstruction for the political (in which, of course, consensus and nonviolence made no appearance):

I am in complete agreement with everything that Ernesto Laclau has said on the question of hegemony and power, and I also agree that in the most reassuring and disarming discussion and persuasion, force and violence are present. Nonetheless, I think that there is, in the opening of a context of argumentation and discussion, a reference-unknown, indeterminate, but nonetheless thinkable - to disarmament. I agree that such disarmament is never simply present, even in the most pacific moment of persuasion, and therefore that a certain force and violence is irreducible, but nonetheless, this violence can only be practiced and can only appear as such on the basis of a non-violence, a vulnerability, and exposition. I do not believe in non-violence as a descriptive and determinable experience, but rather as an irreducible promise and of the relation to the other as essentially noninstrumental. This is not the dream of a beatifically pacific relation, but of a certain experience of friendship perhaps unthinkable today and unthought within the historical determination of friendship in the West. This is a friendship, what I sometimes call an aimance, that excludes violence, a non-appropriative relation to the other that occurs without violence and on the basis of which all violence detaches itself and is determined. $^{22}$

If the political cannot be thought without violence, then, whether antagonistic or not, violence in turn cannot be thought other than against the background of a promise of nonviolence. To find a path between bellicose antagonism and a perhaps naive liberal universalism, the political is to be seen as opened by this promise and by responsibility as much as by divided and conflictual (though not necessarily antagonistic) self- and other-relations. 
Habermas and Mouffe, then, each have half the 'truth' of the political, in that originary sociability indeed comes with the quasi-transcendental or transcendental-pragmatic priority of the higher-order and noninstrumental validity claims of sincerity and truth-telling, even if it is equally necessary that these promises will be betrayed, committing every speech act in advance to a "performative contradiction" (PF 212), and that we not give in to the temptation to think citizenship only on the basis of, against the horizon of, consensus (PF 218):

There is no language without the performative dimension of the promise, the minute I open my mouth I am in the promise. Even if I say that 'I don't believe in truth' or whatever, the minute I open my mouth there is a 'believe me' at work. Even when I lie, and perhaps especially when I lie, there is a 'believe me' in play. And this 'I promise you that I am speaking the truth' is a messianic a priori, a promise which, even if it is not kept, even if one knows that it cannot be kept, takes place. ${ }^{23}$

This nonchosen, heterononomic promise to tell the truth and to abstain from violence, then, entails a "minimum of friendship or consent" (PF 214) as the "law of originary sociability" (PF 231). Aimance as the "anterior affirmation of being-together in allocution" (PF 249) gives rise to a "sort of minimal community" (PF 236), a "community without community" (PF 62). As a result, every political identity, every citizenship, and every social relation, no matter how antagonistic, can only be thought on the basis of a prior affirmation, consent, promise, and friendship. To be sure, such an originary relation is not egalitarian and reciprocal, but rather dissymmetrical and forever nontransparent. But it does hint at the duplicity of social and political relations: needing the other but disavowing the need, the self is also obligated to the other and the other others.

In conclusion, then, it seems we can retain, with modifications and with supplements, the explanatory power of Schmitt's and Mouffe's antagonistic model of politics as conflict, while nonetheless confronting conflict with its other: the promise of consensus and nonviolence we need to construct political horizons, however im-possible, beyond it. Recasting the logic of 
agonism in this way reveals its true use. For given the strong tendencies toward antagonistic exclusion under certain historical and social conditions, 'antagonism' remains a useful tool for political analyses, as Laclau and Mouffe have demonstrated. Their contribution to political theory as well as to current issues in practical politics should primarily be seen in view of the diagnosis of enmity and the problem of political motivation, which tends to be neglected by more rationalistic approaches: motivation for joint emancipatory struggles often does depend, at least in the present, on the opposition toward a common and more concrete 'adversary'. Such an adversary, as Laclau and Mouffe have rightly argued, allows for the co-articulation of different emancipatory movements-anti-racism, anti-sexism, alter-globalization, environmental movements, etc. - along a "chain of equivalences". ${ }^{24}$

The problem, however, is to avoid both the reification of avoidable hostilities as inescapably necessary-Habermas recently spoke of a "disarming ontologization" projection of regulative ideals in all good conscience, that is, as untroubled by urgent demands in the present (whose being met might not obviously contribute to progress), by the danger of particularist usurpations of universality, and by the strong tendencies toward exclusion and even antagonism that affect alleged advances toward the ideal under certain conditions. Both cynicism and a good conscience, as well as both antagonism and all-inclusive ideals, are to be confronted with an unfufillable promise that precedes and exceeds them. An aporetic as opposed to an antagonistic logic may be of help in negotiating these two poles of danger.

\section{Bibliography}

Abizadeh, Arash. "Does Collective Identity Presuppose an Other? On the Alleged Incoherence of Global Solidarity” American Political Science Review 99:1 (February 2005) 45-60. 
Beardsworth, Richard. Derrida and the Political. London, New York: Routledge, 1996.

Derrida, Jacques. Of Grammatology, tr. Gayatri Spivak, Baltimore: Johns Hopkins

University Press, 1976. (cited as OG)

Writing and Difference, tr. Alan Bass, Chicago: University of Chicago Press, 1978.

--------.'Declarations of Independence” New Political Science 15 (1993).

--------. The Politics of Friendship, tr. George Collins. London: Verso, 1997 (cited as PF).

--------. Limited Inc. abc., tr. Samuel Weber, Evanston: North Western University Press, 1988.

--------. Archive Fever. A Freudian Impression, trans. E. Prenowitz. Chicago: University of Chicago Press. 1996.

-------. Specters of Marx. tr. P. Kamuf. New York: Routledge, 1994.

--------. "Autoimmunity: Real and Symbolic Suicides-A Dialogue with Jacques Derrida" Giovanna Borradori, Philosophy in a Time of Terror. Dialogues with Jürgen Habermas and Jacques Derrida, Chicago: University of Chicago Press, 2003

--------. Rogues. Two Essays on Reason. Tr. Pascale-Anne Brault, Michael Naas, Stanford: Stanford University Press, 2005.

Fritsch, Matthias. "Derrida's Democracy To Come" Constellations 9:4 (2002) 574-597.

- The Promise of Memory. History and Politics in Marx, Benjamin, and Derrida, Albany: SUNY Press, 2005.

--------. "Equal Consideration of All-an Aporetic Project?" Philosophy and Social Criticism 32:3 (May 2006) 299-323.

---------. "Cura et Casus: Heidegger and Augustine on the Care of the Self" The Influence of Augustine on Heidegger: The Emergence of an Augustinian Phenomenology, ed. Craig J. N. de Paulo, New York: Edwin Mellen Press, 2006.

Kymlicka, Will. Contemporary Political Philosophy, $2^{\text {nd }}$ ed., Oxford: Oxford University Press, 2002.

Laclau, Ernesto. Emancipation(s). London: Verso, 1996.

Laclau, Ernesto, and Chantal Mouffe. Hegemony and Socialist Strategy. Towards a Radical Democratic Politics. London: Verso, 1985.

Lefebvre, Alexander. "The Political Given: Decisionism in Schmitt's Concept of the Political" Telos 132 (Fall 2005), 83-98.

Naas, Michael. "Comme si, comme ça: Phantasms of Self, State, and a Sovereign God" Mosaic 40:2 (June 2007) 1-26.

Norris, Andrew. "Against Antagonism” Constellations 9:4 (December 2002) 554-573.

Norval, Aletta. "Hegemony after Deconstruction: the Consequences of Undecidability" Journal of Political Ideologies 9:2 (June 2004) 139-157.

Mouffe, Chantal. The Return of the Political. London: Verso, 1993.

--------. (ed.) Deconstruction and Pragmatism, London: Routledge, 1996.

--------. (ed.) The Challenge of Carl Schmitt, London: Verso, 1999.

--------. The Democratic Paradox. London: Verso, 2000 (cited as DP).

--------. On the Political. London: Routledge, 2005.

Thomson, Alex. Deconstruction and Democracy. London: Continuum, 2005.

Schmitt, Carl. The Concept of the Political, ed. George Schwab, Chicago: University of Chicago Press, 1996. (Cited as CP.)

--------. The Crisis of Parliamentary Democracy, tr. Ellen Kennedy, Cambridge: MIT Press, 1985. 


\section{-------. Verfassungslehre, Berlin: Duncker und Humblot, 1993. -------. Theorie des Partisanen, Berlin: Duncker und Humblot, 1963.}

\section{Endnotes}

\footnotetext{
${ }^{1}$ On this shift and the relevant references, see Kymlicka, "Citizenship Theory", in his Contemporary Political Philosophy.

${ }^{2}$ See especially Mouffe, On the Political, chapter four.

${ }^{3}$ I will here not examine the perhaps obvious point that by recasting Schmitt's mortal enemy as an adversary, the relation to the other is too weak to generate the 'we' that Schmitt thought emerges only under the threat of existential annihilation. I believe this is textually but not ontologically correct. See Alexander Lefebvre, "The Political Given: Decisionism in Schmitt's Concept of the Political" Telos 132 (Fall 2005), 83-98.

${ }^{4}$ Derrida, Specters, p. 180, where Derrida says Hegemony presents "a novel elaboration, in a "deconstructive" style, of the concept of hegemony".

${ }^{5}$ Derrida, Writing and Difference, p. 280. Cf. Of Grammatology's "desire for presence" (p. 49) and the "desire for plenitude" in Lim inc., p. $115 \mathrm{ff}$. Below, I will return to this desire, for instance, the desire of a subject to return to itself as the same, while reserving future work for dealing with both potential objections to it and those that have already been made.

${ }^{6}$ Since I don't have the space to engage in detailed textual exegesis of Hegemony here, I limit myself to pointing out that its trajectory refers to Derrida's work at crucial junctures: to the theory of supplementarity (48) and the postSaussurrean critique of the transcendental signified (135f.), which reveals both the impossibility of finally fixing meaning and the ineradicable attempt to nonetheless fix it (111f.), an attempt that leads to antagonism. Of course, Laclau by himself discusses the implications of Derrida's work in other contexts as well; see in particular his "Deconstruction, Pragmatism, Hegemony" in Mouffe (ed.), Deconstruction and Pragmatism and his

Emancipation(s). Some of this work continues the antagonistic thesis by arguing that a 'universal' discourse must be invoked by every particular identity as an attempt to fill its own constitutive lack; thus hegemonizing competition for the universal is inevitable. I also cannot consider in greater detail here the secondary literature that has sprung up around the relation between deconstruction and "radical democracy", most of it also critical of the use of Derrida by Laclau and Mouffe, though generally on different points than the ones I will focus on here; for a start, see Norval, "Hegemony after Deconstruction: the Consequences of Undecidability"; Thomson, Deconstruction and Democracy, chapter three; Abizadeh, "Does Collective Identity Presuppose an Other?" One of the criticisms in this literature concerns the question of whether political relations may, without further ado, be treated on the same level as relations between symbols or signifiers; see Andrew Norris's critique of Laclau in his "Against Antagonism”. I will not deny that Derrida also does this; as we will see, however, paying attention to this transfer from language to politics may help us to avoid unwarranted conclusions.

${ }^{7}$ Cf. Derrida, Rogues, p. 12: "The turn [around the self, returning to the self] makes up the whole and makes a whole with itself; it consists in totalizing, in totalizing itself, and thus in gathering itself by tending toward simultaneity".

${ }^{8}$ As indicated, Mouffe is aware of all three points, but she does not draw the right conclusions from them, namely, that neither exclusion nor antagonism necessarily follow from différance. Awareness of (1) and (3) is expressed by her statement that "In order to be a true outside, the outside has to be incommensurable with the inside, and at the same time, the condition of emergence of the latter. This is only possible if what is 'outside' is not simply the outside of a concrete content but something which puts into question 'concreteness' as such" (DP 12). Recognition of (2) comes in the form of her admission that "if collective identities can only be established on the mode of an us/them, it is clear that, under certain conditions, they can always be transformed into antagonistic relations." She immediately goes on to say, though, that "Antagonism, then, can never be eliminated and it constitutes an ever-present possibility in politics" (DP13). It is precisely this slide from antagonism's 'possibility' to its necessary 'reality' that Derrida detected and criticized in Carl Schmitt (see PF 86).

${ }^{9}$ Derrida, Archive Fever 78; cf. PF 59.

${ }^{10}$ Arash Abizadeh, "Does Collective Identity Presuppose an Other? On the Alleged Incoherence of Global Solidarity" American Political Science Review 99:1 (February 2005) 45-60.

${ }^{11}$ This is why I said earlier (in note six) that we should pay attention to the transfer from linguistic elements to politics: anything can be a sign or a symbol, not only identifiable human others.
} 
${ }^{12}$ Carl Schmitt, Verfassungslehre, cited and discussed in Mika Ojakangas' "Carl Schmitt's Real Enemy: The Citizen of the Non-exclusive Democratic Community?" The European Legacy 8:4 (2003) 411-424, here p. 411.

${ }^{13}$ Jacques Derrida, "Declarations of Independence" in New Political Science 15 (1993). A good analysis of this text in terms of the disjointure or aporia of time is to be found in Richard Beardsworth, Derrida and the Political. London, New York: Routledge, 1996, ch. 3.

${ }^{14}$ See for instance the following passage: "By 'the political' I refer to the dimension of antagonism that is inherent in human relations...I consider that it is only when we acknowledge the dimension of 'the political and understand that 'politics' consists in domesticating hostility and in trying to defuse the potential antagonism that exists in human relations, that we can pose what I take to be the central question for democratic politics" (DP 101, my emphases). See also the passage cited in note 8 .

${ }^{15}$ Here it is tempting to suggest that Mouffe recognizes the logic of differentiation indicated in différance, but underestimates the role of what we have called its deferral aspect.

${ }^{16}$ Rogues, 38. Cf. Rogues 12, and PF 172, cited above. On this ineluctable phantasmatic dimension of selfhood and sovereignty, though not with reference to the projected other or enemy, see Michael Naas, "Comme si, comme ça: Phantasms of Self, State, and a Sovereign God" Mosaic 40:2 (June 2007) 1-26.

${ }^{17}$ See Specters, chapter four, and Derrida, "Autoimmunity: Real and Symbolic Suicides-A Dialogue with Jacques Derrida" in Giovanna Borradori, Philosophy in a Time of Terror. Dialogues with Jürgen Habermas and Jacques Derrida, Chicago: University of Chicago Press, 2003.

${ }^{18}$ With reference to Augustine and Heidegger, I discuss the emergence of responsibility in relation to God in my "Cura et Casus: Heidegger and Augustine on the Care of the Self" The Influence of Augustine on Heidegger: The Emergence of an Augustinian Phenomenology, ed. Craig J. N. de Paulo, New York: Edwin Mellen Press, 2006. ${ }^{19}$ As mentioned, Laclau and Mouffe would add that the construction of specifically collective identity (a) draws on the universal (or what Hegemony called, with Lacan, the nodal points or points de capiton, coming to represent the closure of the discursive field) which it then (b) claims to alone embody, thereby placing the identity in (c) conflictual competition with other particular identities doing the same. I would of course add, once again, that these three moves are perhaps tendencies, not conceptual necessities, though this should not lead us to neglect them altogether.

${ }^{20}$ This is why Derrida would have liked to see Schmitt not just illicitly slide from possibility to actuality (PF 86), but to develop the theoretical tools to rethink their relation, a rethinking that, as we have seen, displaces the object of possible actuality or actual possibility away from 'existential war'.- - I devote a bit more space to the quasitranscendental in my The Promise of Memory, chapter two.

${ }^{21}$ I cannot here unfold the various steps in the argument tying together différance, heteronomic responsibility, and the promise of nonviolent consensus, though I have done so elsewhere (Fritsch, "Paradoxes of Deconstructive Ethics", unpublished ms., and Fritsch, Promise of Memory, chapter four). In "Paradoxes", I also refute Laclau's claim that Derrida's promise is "before any injunction" (Emancipation(s), p. 77) and that, hence, nothing normative follows from quasitranscendentals analysis.

${ }^{22}$ Derrida, "Remarks on Deconstruction and Pragmatism" in Mouffe (ed.), Deconstruction and Pragmatism, p. 83.

${ }^{23}$ Derrida, "Remarks", p. 82.

${ }^{24}$ Laclau, Mouffe, Hegemony, p. 182.

${ }^{25}$ Habermas, "Kulturelle Gleichbehandlung — und die Grenzen des Postmodernen Liberalismus" Deutsche Zeitschrift für Philosophie 51:3, p. 380f. I proposed a reading of Habermas's account of "the limits of postmodern liberalism" in my "Equal Consideration of All—an Aporetic Project?" Philosophy and Social Criticism 32:3, 299-323 (May 2006). 